\title{
Effect of light quality on Tabebuia rosea (Bignoniaceae) seed germination
}

\author{
Sofía Basto ${ }^{1 凶}$, Claudia Ramírez ${ }^{2}$
}

\begin{abstract}
Tabebuia rosea germination capacity and rate have been examined under light and dark conditions. However, seeds responses to light quality, in particular to short and mid-wavelengths, are not well known. We hypothesized that short wavelengths would have a positive effect on T. rosea germination. The effects of short, mid and long-wavelengths on germination capacity, rate (germination rate index, germination rate $\mathrm{R}_{50}$, a devised index of germination rate $\mathrm{R}_{50^{\prime}}$ and peak value), mean daily germination and germination value were evaluated. Light quality had little effect on germination capacity; it was reduced only in darkness. Seeds under short and midwavelengths germinated faster (germination rate) than under any other light treatments. We concluded that although T. rosea seeds respond to all light quality treatments, the short and mid-wavelengths are the cue for increasing germination speed. For synchronizing germination, short and mid-wavelengths transmitted by red cellophane paper can be used as a pre-germinative treatment for restoration and silvicultural purposes.
\end{abstract}

Keywords: Bignoniaceae; short-wavelengths; mid-wavelengths; germination capacity; germination rate; pre-germinative treatments

Edited by Alberto Acosta $\bowtie$

1.Unidad de Ecología y Sistemática, Departamento de Biología,

Facultad de Ciencias, Pontificia Universidad Javeriana, Bogotá,

Colombia.

2. Grupo de Biología de Plantas y Sistemas Productivos, Departamento de Biología, Facultad de Ciencias, Pontificia Universidad Javeriana, Bogotá, Colombia.

Received: 18-07-2014 Accepted: 11-09-2014

Published on line: 19-10-2014

Citation: Basto S, Ramírez C (2015) Effect of light quality on Tabebuia rosea (Bignoniaceae) seed germination. Universitas Scientiarum 20(2): 191199 doi: 10.11144/Javeriana.SC20-2.elqt

Funding: Pontificia Universidad Javeriana.

Electronic supplementary material: N/A

\section{Introduction}

Tabebuia rosea (Bertol.) DC., a member of the Bignoniaceae family, is a tree growing in tropical forests (Woodson et al. 1973) from the sea level to $1,200 \mathrm{~m}$ (Gentry 1992). This species is used for urban ornamentation (Joselin et al. 2013), for furniture and general construction (Petrone \& Preti 2010, Joselin et al. 2013), in agroforestry (Cajas-Giron \& Sinclair 2001, Petrone \& Preti 2010, Plath et al. 2011) and as a medicinal plant (Ugbabe et al. 2010, JiménezGonzález et al. 2013). Even some studies suggest this species might be employed to develop anticancer medicines (Sathiya \& Muthuchelian 2010). T. rosea is also important for its potential use in reforestation and ecological restoration programs (Hernández Gil et al. 2010, Castro-Marin et al. 2011, Plath et al. 2011). This utility is because its management is well-known 
(Suárez et al. 2012), it shows a high survival rate in habitats with different environmental conditions (Wishnie et al. 2007, Hernández Gil et al. 2010, Plath et al. 2011) and grows quickly during its first stages of development (Wishnie et al. 2007). It is also suitable for soil bioengineering techniques used on slopes for restoration and disaster mitigation (Petrone \& Preti, 2010). Because this species has both the potential to be used in ecological restoration (Castro-Marin et al. 2011; Plath et al. 2011) and a high commercial value (Petrone \& Preti 2010, Joselin et al. 2013), its establishment on degraded areas may contribute to ecosystem recovery and to improving the quality of farmers lives (Plath et al. 2011).

Although, the use of local seeds decreases the cost of restoration, most of the projects employ commercial seeds (Prach et al. 2014). Before being used, seeds are usually tested for light and darkness requirements, however these kinds of tests provide little information about the role of the light on regeneration (Tiansawat \& Dalling 2013). Actually, light quality is a key mechanism used by seeds to detect suitable microsites for germination (Tiansawat \& Dalling 2013). This is an important aspect to consider during the restoration processes because in degraded habitats, changes in factors such as light reduce microsite availability and therefore, the possibility of species regeneration and recovery is also limited (Piqueray et al. 2013). Moreover, gaps are created after disturbances that differ in the degree to which they receive direct and transmitted light; large gaps receive a higher R:FR than the smallest (Tiansawat \& Dalling 2013). Furthermore, the proportion of $\mathrm{R}$ and FR are approximately equal in areas receiving unfiltered daylight (Tiansawat \& Dalling 2013).

T. rosea seeds are easily available (Suárez et al. 2012). However, a high variability in germination rate has been recorded, from 7 to 21 days (Sautu et al. 2006) and in germination percentage from 17.7\% (Sady et al. 2010) to $95 \%$ (Castro-Marin et al. 2011), which poses a disadvantage for it's use in restoration. Usually, degraded ecosystems lack safe sites or the set of environmental factors that promote seed germination (Young et al. 2005). So in order to understand the early establishment requirements of this species during the restoration of tropical areas, it is necessary to select the adequate conditions for germination (Celis \& Jose 2011). Moreover, to obtain a source of homogeneous plants to be used in the restoration strategies, the understanding of how to synchronize germination might apply. T. rosea seeds are non-dormant with a fully developed embryo and a permeable seed coat (Sautu et al. 2007). Seeds germinate in a wide range of temperatures (Socolowski \& Takaki 2007), at constant temperature from 20 to $35^{\circ} \mathrm{C}$ regardless of the light conditions (Castro-Marin et al. 2011). The highest synchronization of germination is recorded at $25^{\circ} \mathrm{C}$ in white light and $30^{\circ} \mathrm{C}$ in darkness (Socolowski \& Takaki 2007). However, germination is inhibited by alternating temperatures of $25 / 15^{\circ} \mathrm{C}$ and at constant temperature of $15^{\circ} \mathrm{C}$ (Castro-Marin et al. 2011). Temperature has a lesser effect on germination rate than on germination capacity. There is no difference in the speed of germination at constant temperature between 20 and $35^{\circ} \mathrm{C}$ (Castro-Marin et al. 2011).

T. rosea light requirements for germination are also variable. This species germinates both in open areas and in places where there is no light (Socolowski \& Takaki 2007). Although, there are no changes in germination capacity under light or dark conditions (Castro-Marin et al. 2011), germination rate is higher in light than in darkness (Socolowski \& Takaki 2007). We know that T. rosea germination is not light-dependent (Castro-Marin et al. 2011), however, so far the effect of light quality spectrum on the seed germination of this species has not been recorded. Moreover, there are no studies in the Bignoniaceae family about seed responses to short and mid-wavelengths. However, there is evidence that seeds of some tropical species can respond to blue and green light (Goggin \& Steadman 2012). Both blue and green light may inhibit germination of some herbaceous species (e.g. Amaranthus caudatus (Nowak et al. 1996) and Chondrilla juncea (Luna et al. 2004) respectively). However, it seems that the main effect of blue light is to promote germination of many herbaceous species (e.g. Alysicarpus rugosus (Chaughtai et al. 1983), Amarunthus tricolor (Singhal et al. 1983) and Cyrtopodium glutiniferum (Vogel \& Macedo 2011)). Similar results have been recorded with green light (e.g. Aeschynomene indica and Tephrosia purpurea (Chaughtai et al. 1983). On tropical tree species, blue light increases germination percentage (e.g. Acacia catechu and Butea monosperma (Agrawal \& Prakash 1978). Accordingly, 
we expected short wavelengths would have a positive effect on T. rosea germination. Determining responses to specific wavelengths of the visible spectrum can greatly contribute to the achievement of high and fast germination of seeds sown in the nursery, by easily applying specific wavelengths of transmitted-light. Therefore we conducted an experiment to test whether light quality has an effect on T. rosea germination rate and capacity.

\section{Materials and methods}

Seed moisture content and germination conditions: Commercial seeds of T. rosea were used to examine germination responses to light quality. Because developing and mature seeds detect light in a different way (Goggin \& Steadman 2012), we ensured that $T$. rosea seeds exhibited a similar degree of physiological maturity before being subjected to light quality treatments. For this purpose, seed moisture content was determined by using a digital moisture analyser (O-Haus ${ }^{\circledR}$ MB45). Twenty five randomly selected seeds were weighed and then heated at $105^{\circ} \mathrm{C}$ until the weight stabilized. The measurement was replicated four times following the same protocol. Seed moisture content (MC \%) was expressed on the fresh weight basis (ISTA 2006). We recorded that the average $\mathrm{MC}$ was $7.6 \%$ ( \pm SE 0.1$)$, which showed that seeds were mature before they were hydrated. This percentage is found in the range of maturity of tropical tree species (Ramírez et al. 2008, Jiménez et al. 2009, Peña et al. 2009). Next, T. rosea seeds were sterilised by soaking in a $2.5 \%$ solution of sodium hypochlorite for ten minutes. The time was chosen according to the results of a pre-assay. After rinsing with sterile distilled water five times for one minute, 50 seeds were placed in a Petri dish, for each light quality treatment, with three layers of filter paper (Whatman No. 1) and wetted with $2 \mathrm{ml}$ of distilled water. Each treatment was replicated four times. The Petri dishes were sealed with Parafilm 'M' (Pechiney Plastic Packing, Chicago, Illinois, USA) and incubated in a germination chamber at a constant temperature of $30^{\circ} \mathrm{C}$ under twelve hours photoperiod. Petri dishes were randomly distributed inside the chamber. The experiment was replicated once following the same protocol for sterilising and germination conditions.

Light quality experiment: The coloured light was obtained by covering Petri dishes with two layers of coloured cellophane filter sheets (Dissanayake et al. 2010, Galindo et al. 2012) of red, blue, green and a combination of blue and red. To test germination in the darkness, Petri dishes were covered with two sheets of aluminium foil (Souza et al. 2013). Direct white light (uncovered Petri dishes) was used as the control treatment. Wavelengths absorbed and transmitted by each set of cellophane filter sheets were determined by using a Thermo Scientific Genesys 10S UV-Vis spectrophotometer (Table 1).

Table 1. Wavelengths absorbed and transmitted by two layers of coloured cellophane sheets used as filter to evaluate the effect of light quality on the germination of Tabebuia rosea seeds.

\begin{tabular}{|c|c|c|c|c|}
\hline $\begin{array}{l}\text { Coloured } \\
\text { cellophane }\end{array}$ & $\begin{array}{l}\text { Spectrophotometer } \\
\text { readings }(\mathrm{nm})\end{array}$ & Expected wavelength (nm) & $\begin{array}{c}\text { Transmitted } \\
\text { wavelength }(\mathrm{nm})\end{array}$ & $\begin{array}{c}\text { Representative } \\
\text { wavelength/peak } \\
\text { absorbance (nm) }\end{array}$ \\
\hline Red & $(400-580 \mathrm{~nm})$ & 640-740 (Nobel 2005) & $\begin{array}{l}\text { Violet }(400-425) \\
\text { Blue }(425-490) \\
\text { Yellow }(560-585)\end{array}$ & $\begin{array}{c}660 \mathrm{~nm} \\
(\text { Goggin \& Steadman 2012) }\end{array}$ \\
\hline Blue & $(570-680 \mathrm{~nm})$ & $\begin{array}{c}425-490 \text { (Nobel 2005) } \\
445 \text { (Goggin \& Steadman 2012) }\end{array}$ & $\begin{array}{c}\text { Yellow }(560-585) \\
\text { Orange (585-640) } \\
\text { Red (640-740) }\end{array}$ & $\begin{array}{c}460 \mathrm{~nm} \\
\text { (Nobel 2005) }\end{array}$ \\
\hline Green & $(380-800 \mathrm{~nm})$ & $\begin{array}{c}\text { 490-560 (Nobel 2005) } \\
\text { 526-532 (Goggin \& Steadman 2012) } \\
\text { 530-580 (Goggin \& Steadman 2012) } \\
\text { 577-597 (Dissanayake et al. 2010) } \\
\text { 500-600 (Walck et al. 2000, Folta \& Maruhnich 2007) }\end{array}$ & $\begin{array}{l}\text { UV }(250-400) \\
\text { Violet }(400-425) \\
\text { Blue }(425-490) \\
\text { Green }(500-600) \\
\text { Red }(640-730) \\
\text { Far red }(730-780)\end{array}$ & $\begin{array}{c}520 \mathrm{~nm} \\
\text { (Nobel 2005) }\end{array}$ \\
\hline Blue + Red & $(380-580 \mathrm{~nm})$ & $\begin{array}{c}\text { Above } 740 \text { (Nobel 2005) } \\
730-780(\text { Goggin \& Steadman 2012) }\end{array}$ & $\begin{array}{c}\text { UV (250-400) } \\
\text { Blue }(425-490) \\
\text { Green }(500-600)\end{array}$ & $\begin{array}{c}730 \mathrm{~nm} \\
\text { (Goggin \& Steadman 2012) }\end{array}$ \\
\hline
\end{tabular}


Data collection: Germination was recorded daily for 33 days in a dark room under green light (Souza et al. 2013). The protrusion of the radicle was the criterion for germination. The response variable, number of germinated seeds, was used to calculate the next germination indices, which have been applied to evaluate germination responses of other tropical trees (Jiménez et al. 2009, Peña et al. 2009, Tamayo-Rincón et al. 2010):

a) Germination capacity (GC): shows the percentage of seeds that germinate at the end of the test (Edwards \& El-Kassaby 1996).

b) Germination rate index (GRI): expresses the rate of germination according to the total number of seeds that germinate in a time interval, it is calculated by the formula: GRI $=\mathrm{G} 1 / \mathrm{T} 1+\mathrm{G} 2 /$ $\mathrm{T} 2+\mathrm{G} 3 / \mathrm{T} 3+\ldots \mathrm{Gn} / \mathrm{Tn}$, where, G1=number of germinated seeds on T1; T1=day of first count; $\mathrm{Gn}=$ number of germinated seeds between tn-1 and $\mathrm{Tn}$; $T \mathrm{Tn}=$ day of final count (Maguire 1962).

c) Germination rate $R_{50}$ : indicates the number of days that are required for $50 \%$ of the seeds to germinate (Edwards \& El-Kassaby 1996).

d) A devised index of germination rate $R_{50}$ : indicates the number of days required for $50 \%$ of the germinating seeds to germinate (Thomson \& El-Kassaby 1993).

e) Peak value (PV): expresses the maximum quotient derived from the cumulative germination percentage by the number of days required to reach this percentage (Czabator 1962).

f) Mean daily germination (MDG): is the average number of seeds germinating per day of the definite test period (Czabator 1962).

g) Germination value $(\mathrm{GV})$ : is an index that combines speed and total germination and it is calculated with the formula GV $=\mathrm{PV} \times \mathrm{MDG}$ (Czabator 1962).

Statistical analysis: The germination indices data were analysed by one-way ANOVA using the General Linear Models (GLM) procedure of the the Statistical Analysis System program (SAS version 9.2, SAS Institute, Cary, NC, USA). Each calculated index with significant F-tests $(\mathrm{P} \leq 0.05)$ were compared using Duncan's multiple range test of the same statistical package.
To explain the response of each germination index to the light treatments applied, and to find differences between them, the results were analyzed according to this model:

$$
\mathrm{Yij}=\mu+\mathrm{F} 1+\varepsilon
$$

where,

Yij $=$ Germination responses (germination indices)

$\mu=$ General media effect

F1 = Treatment effect (light quality)

$\varepsilon=$ Experimental error

According to this design, in which the variation is due only to the treatment (light quality), the statistical analysis indicate the behaviour of each index in relation to the treatment. Therefore, the indices were analysed independently.

\section{Results}

The results indicate that the seed moisture content, recorded before they were hydrated and light treatments were applied, was suitable for the germination process. Moreover, these results indicate that $T$. rosea seeds were not dormant.

Spectrophotometer readings: In most cases, spectrophotometer readings indicated that there were differences between the absorbed and the expected wavelengths for each coloured cellophane filter sheet. Absorbed, expected and transmitted wavelengths are shown in Table 1. Red cellophane did not absorb light from the representative wavelength (absorption peak to $660 \mathrm{~nm}$ ); however, it transmitted a radiation in the range of 400-580 nm, corresponding to short and midwavelengths (Table 1). When blue cellophane was used, a radiation in the range of $570-680 \mathrm{~nm}$ was transmitted, corresponding to mid and long-wavelengths (Table 1). Green cellophane transmitted a wide radiation in the range of $380-800 \mathrm{~nm}$, corresponding to short, mid and long-wavelengths (Table 1). In addition, this cellophane paper transmitted wavelengths similar to the range of the visible spectrum $(400-700 \mathrm{~nm})$. The combination of blue and red cellophane transmitted a radiation range of $380-580 \mathrm{~nm}$, corresponding to short and mid-wavelengths of the spectrum (Table 1). 
Light quality effect on cumulative germination of T. rosea: Germination curves for light treatments showed a sigmoidal pattern with three well-defined phases (Figure 1). The three phases started early with red cellophane filter sheets (short and midwavelengths). The first, covering the period between sowing and the start of germination, lasted five days. The second, comprising the period in which most seeds germinated, lasted between six and thirteen days. The third phase, covering the period in which the maximum number of germinated seeds has been reached, started from the thirteenth day.

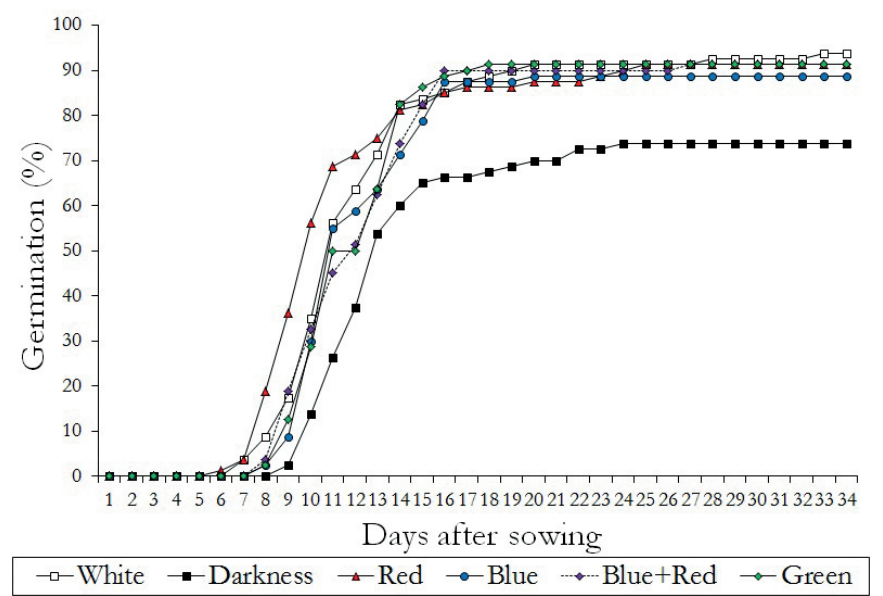

Fig. 1. Cumulative germination curves for T. rosea seeds under light quality treatments. Germination curves showed a sigmoidal pattern with three phases. The first includes the period from the beginning of sowing to the onset of germination; the second covers the period in which most seeds germinated and, the third indicates the period in which the maximum number of germinated seeds has been reached. The three germination phases started early with the red cellophane filter. The colours are those of the coloured cellophane filter sheets. Red (short and mid-wavelengths), blue (mid and longwavelengths), blue+red (short and mid-wavelengths) and green (short, mid and long wavelengths).

Light quality effect on the capacity and rate of germination of $T$. rosea: The main effect of light quality was recorded on germination rate. Seeds under red cellophane filter (short and mid-wavelengths) germinated faster than seeds under any other light treatments, and longer in darkness. Significant differences were recorded for the indices $R_{50}$ (One-way ANOVA; F = 7.8; df = 5, 23; $\mathrm{p}<0.001$ ),
Table 2. Effect of light quality on Tabebuia rosea germination indices. GC: germination capacity, GRI: germination rate, $\mathrm{R}_{50}$ : germination rate, $\mathrm{R}_{50}$ : devised index of germination rate, PV: peak value, MDG: mean daily germination and GV: germination value. (See methods for details on germination indices). Means with different letters indicate significant differences according to Duncan's test $(\mathrm{P}<0.05)$. The colours are those of the coloured cellophane filter sheets. Red (short and mid-wavelengths), blue (mid and longwavelengths), blue+red (short and mid-wavelengths) and green (short, mid and long wavelengths)

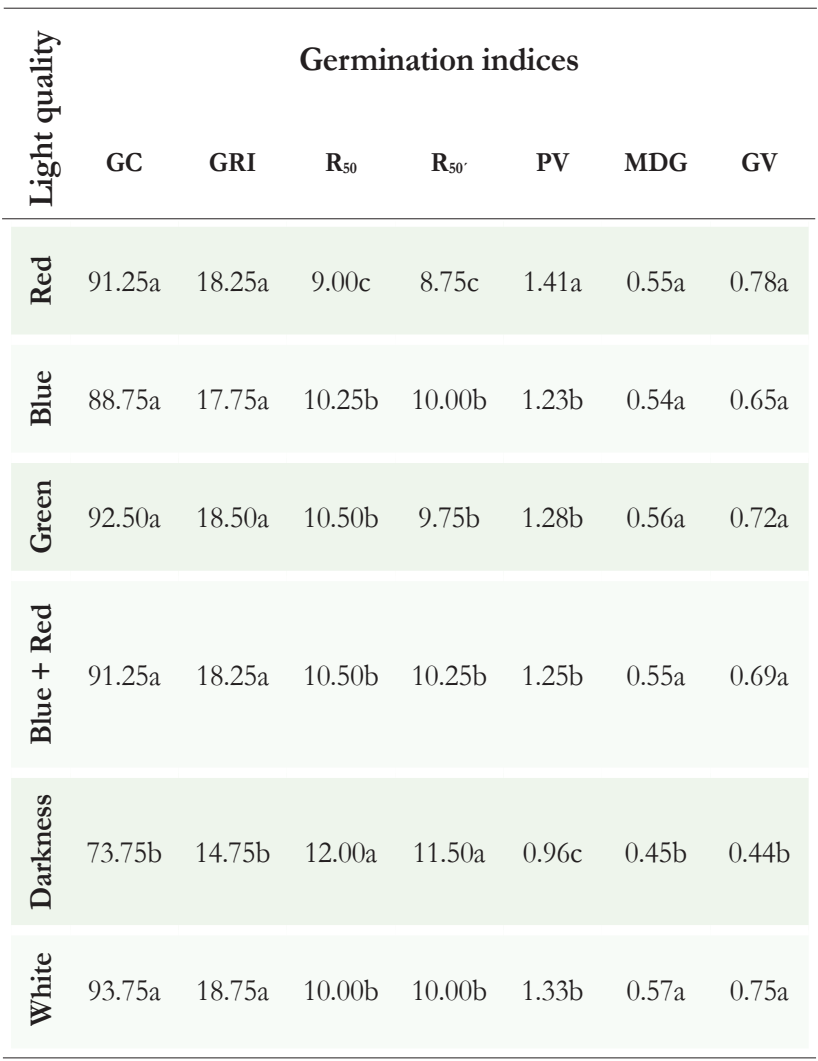

$\mathrm{R}_{50^{\circ}}$ (One-way ANOVA; $\mathrm{F}=6.1 ; \mathrm{df}=5,23 ; \mathrm{p}<0.01$ ) and PV (One-way ANOVA; F = 5.3; $\mathrm{df}=5,23$; $\mathrm{p}$ $<0.05$ ) (Table 2). Moreover, on each observation time interval, as GRI index showed, the total number of germinating seeds was reduced significantly in darkness (One-way ANOVA; F = 3.4; df = 5, 23; p $<0.05$ ) (Table 2). The lack of light also significantly reduced other germination parameters (Table 2). MDG (One-way ANOVA; $\mathrm{F}=4.4 ; \mathrm{df}=5,23 ; \mathrm{p}<$ 0.05), GV (One-way ANOVA; F = 3.4; df = 5, 23; p $<0.001$ ) and GC (One-way ANOVA; $\mathrm{F}=3.4$; $\mathrm{df}=$ 5, 23; $\mathrm{p}<0.05$ ) (Figure 2) showed the lowest values in darkness. 


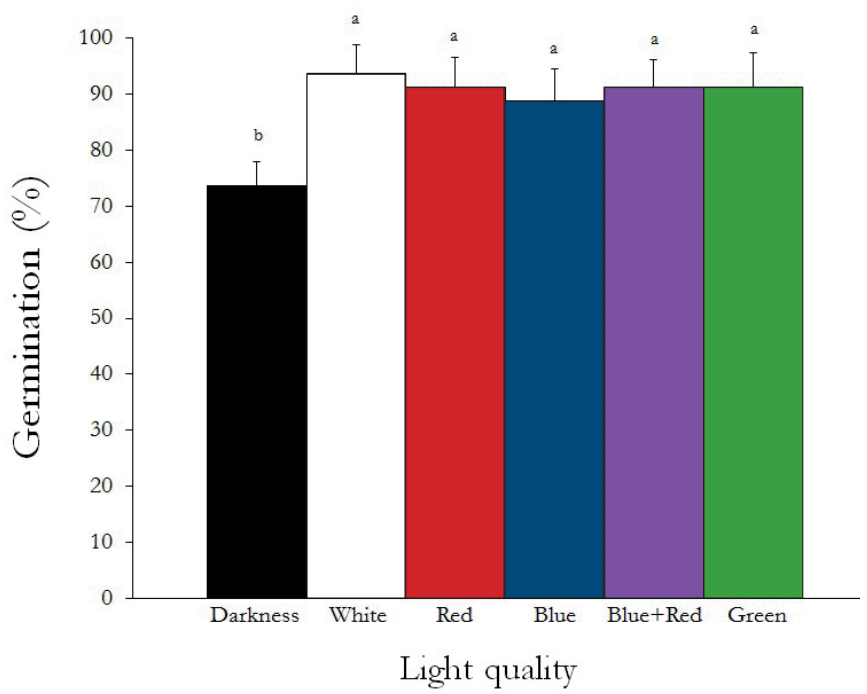

Fig. 2. Effect of light quality on Tabebuia rosea seed germination capacity (GC). GC was significantly reduced when seeds were incubated in darkness. Bars indicate mean + SE. Means with the same letters do not differ significantly ( $\mathrm{P}>0.05)$ according to Duncan's multiple range test. The colours are those of the coloured cellophane filter sheets. Red (short and mid-wavelengths), blue (mid and long-wavelengths), blue + red (short and mid-wavelengths) and green (short, mid and long wavelengths).

\section{Discussion}

Evidence shown blue and green light has a role in the regulation of several vegetative developmental and physiological processes (Wang \& Folta 2013, Goggin \& Steadman 2012, Folta \& Maruhnich 2007, Christophe et al. 2006). However, few studies addressed the effect of these wavebands on seeds (Goggin \& Steadman 2012). Our study contributes to the understanding of the responses of seeds of tropical trees to short and mid-wavelengths. T. rosea germination rate was higher with short and mid-wavelengths. We suggest that seed responses to blue light may be due to the action of one or more specific blue-light photoreceptors (cryptochromes and phototropins). Blue light receptors have been well studied in vegetative tissues, however their role in seed light perception is largely unknown (Goggin et al. 2008, Goggin \& Steadman 2012). Furthermore, evidence has shown that green light induces several responses in plants that cannot be explained by the action of any of the known photoreceptors and some seeds, apparently, are capable of perceiving green light (Goggin \& Steadman 2012, Wang \& Folta 2013, Christophe et al. 2006, Luna et al. 2004). By cryptochrome-dependent and cryptochrome-independent mechanisms, green light has an effect on plant processes which are opposite to those caused by red and blue wavebands (Folta \& Maruhnich 2007). However, according to our results, short and mid-wavelengths promote $T$. rosea seed responses.

On the other hand, darkness had a negative effect on seed germination. Unlike other studies (Castro-Marin et al. 2011), we recorded a decrease in germination capacity under dark conditions. However, germination rate was lower in darkness than in light as it has been recorded previously (Socolowski \& Takaki 2007). Together, our results suggest that the mechanism of dark reversion, the slow conversion of Pfr form of phytochrome into the Pr form, was maybe attenuated (Kircher et al. 2012), and therefore darkness did not completely inhibit T. rosea germination. Overall, T. rosea showed a high germination percentage under all light quality treatments. This result indicates that the germination responses of this species may be mediated by both the phytochrome and other photoreceptors. Although members of the phytochrome family efficiently perceive red and far-red light, they are also capable of absorbing other wavelengths (Goggin et al. 2008, Goggin \& Steadman 2012).

Our approach can be applied to accelerate and synchronize germination of T. rosea, which is useful in silviculture to increase the production of plant material in nurseries, and to define arrangements and densities for the establishment of plantations. Mostly, our study has some implications for restoration. Although the light requirement for germination of its seeds is wide, short and mid-wavelengths contribute to speeding up and synchronizing germination. Specifically, the results suggest that restoration practices of tropical degraded-habitats with $T$. rosea would highly benefit if seeds are sowed: 1) during the intermediate stages of the restoration; 2) near other plants or under foliage; and 3) under blue light 
or by using red cellophane paper in a greenhouse or at nursery stage to increase and synchronize germination, which is highly recommended in restoration projects (Prach et al. 2007). Moreover, our results can be used to select appropriate microsites to sow seeds in the field for the restoration of tropical degraded-habitats, and to increase natural population sizes of T. rosea. Finally, a similar approach may be addressed during the planning stage of restoration projects to identify species with the highest potential to be successfully established from seeds in degraded ecosystems.

For future studies, we recommend confirmation of the results of the effect of light quality on seed germination, by using filters that guarantee the absorption and transmission of the wavelengths of each representative radiation of the visible spectrum. Moreover, we suggest conducting studies leading to the understanding of the seed responses to flow rate and photon flux density.

\section{Conclusions}

T. rosea seeds respond to all light quality treatments. According to our hypothesis, short and midwavelengths have a positive effect on $T$. rosea germination, specifically on parameters related to cumulative germination, capacity and germination rate. This knowledge contributes to our understanding of tropical tree seed responses to wavelengths other than the long-wavelengths, which have been studied more. In addition, the lack of light has a negative impact on T. rosea germination responses. Moreover, determining responses to specific wavelengths of the visible spectrum can greatly contribute to the achievement of a high and fast germination of seeds sown in the nursery, by easily applying specific wavelengths of transmitted-light.

\section{Acknowledgements}

We acknowledge the support of Pontificia Universidad Javeriana. We also acknowledge to the anonymous reviewers for helpful comments on the manuscript.

\section{Conflicts of interest}

We declare no conflict of interest regarding the results published in this work.

\section{References}

Agrawal PK, Prakash G. (1978) Control on seed germination in some Indian trees. Tropical Ecology 19(2):174-177.

Cajas-Giron YS, Sinclair FL (2001) Characterization of multistrata silvopastoral systems on seasonally dry pastures in the Caribbean Region of Colombia. Agroforestry Systems 53:215-225 doi: 10.1023/A:1013384706085

Castro-Marin G, Tigabu M, Gonzalez-Rivas B, Oden PC (2011) Germination requirements and seedling establishment of four dry forest species from Nicaragua. Tropical Ecology 52(1):1-11

Celis G, Jose S (2011) Restoring abandoned pasture land with native tree species in Costa Rica: Effects of exotic grass competition and light. Forest Ecology and Management 261:1598-1604 doi: 10.1016/j.foreco.2010.10.005

Chaughtai SA, Khan SS, Sultan S (1983). Germination response of some wild papilionaceous seeds of various action spectra. Biologia 29:93-100

Christophe A, Moulia B, Varlet-Grancher C (2006). Quantitative contributions of blue light and PAR to the photocontrol of plant morphogenesis in Trifolium repens (L.). Journal of Experimental Botany 57(10):2379-2390. doi: $10.1093 / \mathrm{jxb} / \mathrm{erj} 210$

Czabator FJ (1962) Germination value: An index combining speed and completeness of pine seed germination. Forest Science 8:386-396

Dissanayake P, George DL, Gupta ML (2010) Effect of light, gibberellic acid and abscisic acid on germination of guayule (Parthenium argentatum Gray) seed. Industrial Crops and Products 32:111-117 doi: 10.1016/j. indcrop.2010.03.012

Edwards DGW, El-Kassaby YA (1996) The effect of stratification and artificial light on the germination of mountain hemlock seeds. Seed Science and Technology $24: 225-235$

Folta KM, Maruhnich SA (2007) Green light: a signal to slow down or stop. Journal of Experimental Botany 58(12):3099-3111 doi: 10.1093/jxb/erm130

Gentry AH (1992) Bignoniaceae: Part II (Tribe Tecomeae). Flora Neotropica 25(2):1-370

Galindo E, Alves EU, Silva KB, Matos BL, da Silva SMS (2012) Germinação e vigor de sementes de Crataeva tapia L. em diferentes temperaturas e regimes de luz. Revista Ciência Agronômica 43(1):138-145

Goggin, DE, Steadman, KJ (2012) Blue and green are frequently seen: responses of seeds to short- and mid-wavelength light. Seed Science Research 22:27-35 doi: $10.1017 /$ S0960258511000444 
Goggin DE, Steadman KJ, Powles SB (2008) Green and blue light photoreceptors are involved in maintenance of dormancy in imbibed annual ryegrass (Lolium rigidum) seeds. New Phytologist 180:81-89 doi: 10.1111/j.14698137.2008.02570.x

Hernández Gil R, Rada F, Silva R (2010) Crecimiento y desarrollo en plantas juveniles de apamate (Tabebuia rosea (Bertol.) A. DC.) sometidas a inundación. Pittieria 34:113-126

ISTA (2006) International rules for seed testing. International Seed Testing Association (ISTA). Bassersdorf, Switzerland

Jiménez-González FJ, Veloza LA, Sepúlveda-Arias JC (2013) Anti-infectious activity in plants of the genus Tabebuia. Universitas Scientiarum 18(3):257-267 doi: 10.11144/Javeriana.SC18-3.aapg

Jiménez-L KE, Escobar-Torres W, Ramírez-Sandoval C (2009) Fisiología de Semillas de Maclura tinctoria (L.) D. Don ex Steud (Dinde). En: Rodríguez JM, Camargo, JC, Niño J, Pineda AM, Arias LM, Echeverri MA, Miranda CL (eds) Valoración de la Biodiversidad en la Ecorregión del Eje Cafetero. CIEBREG, Pereira, Colombia, pp 41-57

Joselin J, Brintha TSS, Florence AR, Jeeva S (2013) Phytochemical evaluation of Bignoniaceae flowers. Journal of Chemical \&Pharmaceutical Research 5(4):106-111

Kircher S, Bauer D, Schäfer E, Nagy F (2012) Intramolecular uncoupling of chromophore photoconversion from structural signaling determinants drive mutant phytochrome B photoreceptor to far-red light perception. Plant Signaling \& Behavior 7:904-906 doi: $10.4161 / \mathrm{psb} .20714$

Luna B, Pérez B, Fernández-González, F \& Moreno JM (2004) Sensitivity to green safelight of 12 Mediterranean species. Seed Science and Technology 32(1):113-117.

Maguire JD (1962) Speed of germination-aid in selection and evaluation for seedling emergence and vigor. Crop Science 2:176-177.

Nobel PS (2005) Physicochemical and Environmental Plant Physiology. Elsevier, Inc. USA.

Nowak J, Rudnicki RM, \& Grzesik M (1996) Effect of light quality on seed germination, seedling growth and pigment content in Amarantbus caudatus and Celosia cristata nana. Journal of Fruit and Ornamental Plant Research 4:179-185

Peña-Jiménez L, Ramírez-Sandoval C, Escobar-Torres W (2009) Fisiología de Semillas y Propagación Sexual de Magnolia hernandezii (Molinillo) En: Rodríguez JM, Camargo JC, Niño J, Pineda AM, Arias LM, Echeverri MA, Miranda CL. (eds) Valoración de la Biodiversidad en la Ecorregión del Eje Cafetero. CIEBREG, Pereira, Colombia, pp 61-57
Petrone A, Preti F (2010) Soil bioengineering for risk mitigation and environmental restoration in a humid tropical area. Hydrology \& Earth System Sciences 14:239-250

Piqueray J, Saad L, Bizoux JP, Mahy G (2013) Why some species cannot colonise restored habitats? The effects of seed and microsite availability. Journal for Nature Conservation 21:189-197 doi: 10.1016/j.jnc.2012.12.005

Plath M, Mody K, Potvin C, Dorn S (2011) Do multipurpose companion trees affect high value timber trees in a silvopastoral plantation system? Agroforestry Systems 81:79-92 doi: 10.1007/s10457-010-9308-9

Prach K, Marrs R, Pyšek P, van Diggelen R (2007) Manipulation of succession. In: Walker LR, Walker J, Hobbs RJ (eds) Linking Restoration and Ecological Succession. Springer Verlag, New York, USA, pp. 121-149

Prach K, Jongepierová I, Řehounková K, Fajmon K (2014) Restoration of grasslands on ex-arable land using regional and commercial seed mixtures and spontaneous succession: successional trajectories and changes in species richness. Agriculture, Ecosystems \& Environment. 182:131-136 doi: 10.1016/j.agee.2013.06.003

Ramírez C, Hilhorst HWM \& Hodson E (2008) Viability and seed germination of Passiflora mollissima (HBK) Bailey according to provenance and fruit ripening stage. En: Memorias Red Alfa Lagrotech 2005-2008. Editorial Dupligráficas, Bogotá, Colombia, pp:145-190.

Sady GC, Holl KD, Cole RJ, Zahawi RA (2010) Germination and survival of tree seeds in a tropical montane forest restoration study (Costa Rica). Ecological Restoration 28:121-124 doi: 10.3368/er.28.2.121

Sathiya M, Muthuchelian K (2010) Antitumor potential of total alkaloid extract from Tabebuia rosea (Bertol.) DC. leaves on MOLT-4 cells in vitro. Nature and Science 8(9):77-85

Sautu A, Baskin JM, Baskin CC, Condit R (2006) Studies on the seed biology of 100 native species of trees in a seasonal moist tropical forest, Panama, Central America. Forest Ecology and Management 234:245-263 doi: 10.1016/j.foreco.2006.07.006

Sautu A, Baskin JM, Baskin CC, Deago J, Condit R (2007) Classification and ecological relationships of seed dormancy in a seasonal moist tropical forest, Panama, Central America. Seed Science Research 17:127-140 doi: 10.1017/S0960258507708127

Singhal BK, Sen DN, \& Bhandari DC (1983). Spectral sensitivity of seed germination and seedling growth in Amaranthus species. Bangladesh Journal of Botany 12:171-177

Socolowski F, Takaki M (2007) Germinação de sementes e emergência de plântulas de Tabebuia rosea (Bertoloni) A.P. de Candolle (Bignoniaceae), uma espécie exótica com potencial invasor. Revista Arvore 31(2):229-238 
Souza MC, do Amaral CL, Tozzi HH, Alves PLDCA (2013) Germination performance of yellow cosmos: Understanding its invasion under tropical conditions. Journal of Agricultural Science 5:56-62 doi: 10.5539/jas. v5n4p56

Suárez A, Williams-Linera G, Trejo C, ValdezHernández JI, Cetina-Alcalá VM, et al. (2012) Local knowledge helps select species for forest restoration in a tropical dry forest of central Veracruz, Mexico. Agroforestry Systems 85:35-55 doi: 10.1007/s10457011-9437-9

Tamayo-Rincón M, Rodríguez-Pérez L, Escobar-Torres W (2010) Estudio de la propagación sexual del arboloco Montanoa quadrangularis Schultz Bipontianus Asteraceae. Universitas Scientiarum 15(1):37-48

Thomson AJ, El-Kassaby YA (1993) Interpretation of seed-germination parameters. New Forests 7:123-132 doi: 10.1007/BF00034195

Tiansawat P, Dalling JW (2013) Differential seed germination responses to the ratio of red to far-red light in temperate and tropical species. Plant Ecology 214:751-764 doi: 10.1007/s11258-013-0205-y

Ugbabe GE, Ayodele AE, Ajoku GA, Kunle OF, Kolo I, et al (2010) Preliminary phytochemical and antimicrobial analyses of the leaves of Nigerian Bignoniaceae Juss. Global Research Journals 1:1-5

Efecto de la calidad de la luz en la germinación de Tabebuia rosea (Bignoniaceae)

Resumen. La capacidad y tasa de germinación de las semillas de Tabebuia rosea han sido evaluadas bajo condiciones de luz y oscuridad. Sin embargo, aún se desconocen las respuestas a la calidad de la luz, particularmente a las longitudes de onda corta y media del espectro. Nuestra hipótesis fue que las longitudes de onda corta podrían tener un efecto positivo en la germinación de T. rosea. Se evaluaron los efectos de las longitudes de onda corta, media y larga sobre la capacidad germinativa, la tasa de germinación (índice de la tasa de germinación, tasa de germinación $R_{50}$ y $R_{50}$ y valor pico), germinación media diaria y valor de germinación. La calidad de la luz tuvo poco efecto en la capacidad de germinación, la cual se redujo únicamente en condiciones de oscuridad. Aunque las semillas de T. rosea respondieron de manera similar en todas las condiciones de luz evaluadas, se presentó un incremento en la velocidad de germinación cuando las semillas se sometieron a longitudes de onda corta y media, las cuales incidieron de manera positiva en la sincronización del proceso de germinación. Estos hallazgos son aplicables para la restauración y en estrategias de producción de plántulas para proyectos de silvicultura.

Palabras clave: Bignoniaceae; longitudes de onda corta; longitudes de onda media; capacidad de germinación; tasa de germinación; tratamientos pregerminativos
Vogel IN \& Macedo AF (2011) Influence of IAA, TDZ, and light quality on asymbiotic germination, protocorm formation, and plantlet development of Cyrtopodium glutiniferum Raddi., a medicinal orchid. Plant Cell, Tissue and Organ Culture 104, 147-155

Walck JL, Baskin JM, Baskin C (2000) Increased sensitivity to green light during transition from conditional dormancy to nondormancy in seeds of three species of Solidago. Seed Science Research 10:495-499

Wang Y \& Folta KM (2013) Contributions of green light to plant growth and development. American Journal of Botany 100(1):70-78. 2013.

Wishnie MH, Dent DH, Mariscal E, Deago J, Cedeno $\mathrm{N}$, et al. (2007) Initial performance and reforestation potential of 24 tropical tree species planted across a precipitation gradient in the Republic of Panama. Forest Ecology and Management 243:39-49 doi: 10.1016/j. foreco.2007.02.001

Woodson RE, Schery RW, Gentry AH (1973) Flora of Panama. Part IX. Family 172. Bignoniaceae. Annals of the Missouri Botanical Garden 60:781-977 doi: $10.2307 / 2395140$

Young TP, Petersen DA, Clary JJ (2005) The ecology of restoration: historical links, emerging issues and unexplored realms. Ecology Letters 8:662-673 doi: 10.1111/j.1461-0248.2005.00764.x

Efeito da qualidade da luz na germinaçáo de Tabebuia rosea (Bignoniaceae)

Resumo. Examinou-se a taxa e a capacidade de germinação de Tabebuia rosea em condições de luz y escuridão; no entanto, a resposta das sementes para da qualidade da luz, em particular aos comprimentos de onda curto e médio não são bem conhecidos. Nossa hipótese é que os comprimentos de onda curtos têm um efeito positivo sobre a germinação de T. rosea. Os efeitos de curto, médio e longo comprimentos de onda sobre a capacidade de germinação, taxa (índice de velocidade de germinação, velocidade de germinação $R_{50}$ e $R_{50^{\prime}}$ e valor de pico), média de germinação diária e valores de germinação foram avaliados. A qualidade da luz teve pouco efeito sobre a capacidade de germinação; a germinação decresceu apenas na escuridão. A taxa de germinação de sementes sob curto e médio comprimentos de onda foi mais rápido do que em quaisquer outras condições de luz; comprimento de onda curto não teve nenhum efeito significativo sobre os parâmetros de germinação. Concluímos que, embora as sementes T. rosea respondem a todos os tratamentos de qualidade de luz, os comprimentos de onda curto e médio aceleram a velocidade de germinação. Para sincronizar a germinação, ondas de curto e médio comprimento transmitidas através de papel celofane vermelho podem ser usadas como um tratamento prégerminativo para a restauração e para fins silvícolas.

Palavras-chave: Bignoniaceae; comprimentos de onda curta; comprimentos de onda médios; capacidade de germinação; taxa de germinação; pré-germinativo 